\section{Further iteration towards reform}

Tokyo

Arrempts to reform Japan's educational system have taken another halting step forward with the publication last Thursday of Prime Minister Yasuhiro Nakasone's Special Educational Advisory Council's second full-length report.

The report met the barrage of criticism that has greeted every pronouncement of the special council (see Nature 319, 347; 1986) and was preceded by the publication of counter-reports from women's groups, teachers groups and unions, proving, as other nations have found, that although it may be hard to effect educational reform, it is certainly not hard to whip up opposition to it. In the new report, for the first time, details begin to emerge of how universities might be reformed.

The central criticisms of the universities are that they are too inflexible, too homogeneous and do not make a contribution to the international research community commensurate with Japan's status as a world power. Furthermore, the universities are resistant to change and do not sufficiently influence educational policy.

The solution to this last problem is seen in the establishment of a "university council" which would have the right of direct access to the Minister of Education, Science and Culture. Its brief would be wide: as well as conducting surveys and collecting information, it would expect to proffer advice on the structure of the universites, their planning and construction, on what areas needed developing to provide trained manpower, the content of university education and the methods of teaching. There are at present a number of bodies representing the universities but none that can speak for all universities including state and private universities and the junior (two-year) colleges.

To the problems of inflexibility and homogeneity come one familiar solution: the use of a credit system that would allow students to transfer between faculties, or even universities. If necessary, a special institution should be set up to grant degrees to those who have gained sufficient credits from several sources. Inputs to the universities could be made more diverse with quotas set for the enrolment of ordinary citizens and junior college graduates into the four-year universities.

Suggestions for the reform of university research begin with the surprising statistic that the ratio of graduate students to undergraduate students in Japan is the lowest of all the developed countries. In part, of course, this reflects the high number of engineering students who quickly enter industry. Less surprising is the recognition of the lack of technical back-up in the universities: the general rule is that if you want a piece of equipment you must build it yourself. To bring about reform, young people need better treatment.

The report gives the average age for completion of a $\mathrm{PhD}$ course as 27. To make things move faster, it is suggested that it should be made possible to complete a master's course in one year and a doctoral course in three years, with direct possible for especially talented students.

Postdoctoral fellowships (of which there are still only a few hundred in Japan) should be made much more easily available. And thought should go to the establishment of an independent graduate university for research students. This is something those in the new research institutes for joint use by universities (like those at Okazaki) would particularly welcome, for without attachment to any particular university they have no ready source of graduate students. A graduate university could well find a home at Okazaki.

The role of "joshu", the lowly position of research assistant which is often the first entry to a doctoral course after graduation

\section{Soviet science}

THIS year's Lenin Prizes for Science and Technology in the Soviet Union concentrate on fundamental research. Only two of the eight prizes awarded last week have any immediate relevance to the application of research results in production, hailed for the past two decades as the principal target for Soviet science.

Pravda's editorial preamble to the review of the prizes by Academician Anatolii Aleksandrov, president of the Soviet Academy of Sciences, still emphasizes the need to "accelerate scientific and technical progress", but the stress is now on the mobilization of "creative forces" in science rather than on the rapid implementation of results.

All but one of the awards are cumulative, for "cycles" of research and publications going back, in some cases, more than 20 years. The exception is the prize for Yurii Aleksandrov and his team from the Institute of Radio and Electronics of the Soviet Academy of Sciences and the Special Design Bureau of Moscow University, who won the prize for developing a special radar system for mapping the surface of Venus from the Venera-15 and Venera-16 probes. (This is the only prizewinning work for which Academician Aleksandrov mentions spin-off; the system, he says, has also been applied in the study of flooding, irrigation, salination, and soil and water studies in many parts of the Soviet Union.) rung on the ladder to professor but which is sometimes mistaken by professors as a post providing personal attendants, also needs to be looked at afresh, the report says. Low staff turnover is another problem: possible solutions are the usual early retirement, untenured short-term posts and contract research.

Reforms are, of course, expensive, particularly the provision of increased technical assistance, more fellowships, graduate universities and increased foreign exchange. The report points out that 330 thousand million yen will be spent on academic research this year. But estimates of how much reform of postgraduate education would cost suggest that the same amount again would need to be spent over the next ten years. This is unlikely to find favour with the Ministry of Finance, which is already complaining that spending on education is high enough. How high is high enough is hard to measure: the Japan Teachers Union claims that Japan's 1985 education budget accounted for 4.6 per cent of its gross national product compared with 9.1 per cent in Sweden, 8.1 per cent in The Netherlands, 7.2 per cent in the Soviet Union and 6.4 per cent in the United States.

\title{
Lenin prizes return to basics
}

The longest "cycle" to be honoured is that of Academician Grigorii Devatykh, for his development of methods of obtaining high-purity volatile substances, which he began in 1959. Almost as early, and far more significant, is the starting date assigned to Dr Roman Khesin-Lur'e's work on "molecular principles of the functioning of the genome", which he apparently began to publish in 1960 . Lysenkoism was then in full swing, and, according to the Soviet biological establishment, the gene was considered an "empty abstraction", accepted only by reactionaries. It would be interesting to know where Khesin-Lur'e published his work at that time, and what part, if any, he played in the overthrow of Lysenkoism.

Another interesting award is that for "inclusive processes in strong interactions of high-energy elementary particles and the discovery of scale invariance in these processes". Aleksandrov goes out of his way to stress that the new directions opened up by the work done at Serpukhov were afterwards confirmed at CERN and the Fermi National Accelerator Laboratory in the United States, and the team includes not only Soviet citizens but also Dr Nguyen Van Hue, president of the Vietnamese National Centre for Scientific Research. Lenin prizes are normally a purely Soviet affair, but this year there seems to have been a greater emphasis on their place in world science. Vera Rich 